\title{
A new programme for monitoring the mass loss of the Greenland ice sheet
}

\author{
Andreas P. Ahlstrøm and the PROMICE project team*
}

The Greenland ice sheet has been losing mass at a dramatic rate in recent years, raising political concern worldwide due to the possible impact on global sea level rise and climate dynamics (Luthcke et al. 2006; Rignot \& Kanagaratnam 2006; Velicogna \& Wahr 2006; IPCC 2007; Shepherd \& Wingham 2007). The Arctic region as a whole is warming up much more rapidly than the globe at large (ACIA 2005) and it is desirable to quantify these changes in order to provide the decision-makers with a firm knowledge base. To cover this need, the Danish Ministry of Climate and Energy has now launched a new Programme for Monitoring of the Greenland Ice Sheet (PROMICE), designed and operated by the Geological Survey of Denmark and Greenland (GEUS) in collaboration with the National Space Institute at the Technical University of Denmark and Asiaq (Greenland Survey). The aim of the programme is to quantify the annual mass loss of the Greenland ice sheet, track changes in the extent of local glaciers and ice caps, and track changes in the position of the ice-sheet margin.

\section{Observing and modelling the ice-sheet surface-mass balance}

Surface mass balance will be estimated using data from a new network of automatic mass-balance stations (AMS) on the margin of the Greenland ice sheet (Fig. 1). The final station network will include a total of 14 stations located in seven climatically different regions of the Greenland ice sheet and is intended to be fully operational from 2011. At each location, one station will be placed in the lower ablation zone, and another in the higher ablation zone near the equilibrium-line altitude. Currently, six of these stations are operational in four regions of the ice-sheet margin (Fig. 1). The PROMICE network will complement the U.S. Greenland Climate Network (GC-Net) which consists of $c .15$ stations, mainly in the accumulation zone of the ice sheet (Steffen \& Box 2001) and the Dutch K-transect of three stations on the icesheet margin near Kangerlussuaq, West Greenland (Fig. 1; van de Wal et al. 2005). This collaboration means that ice-

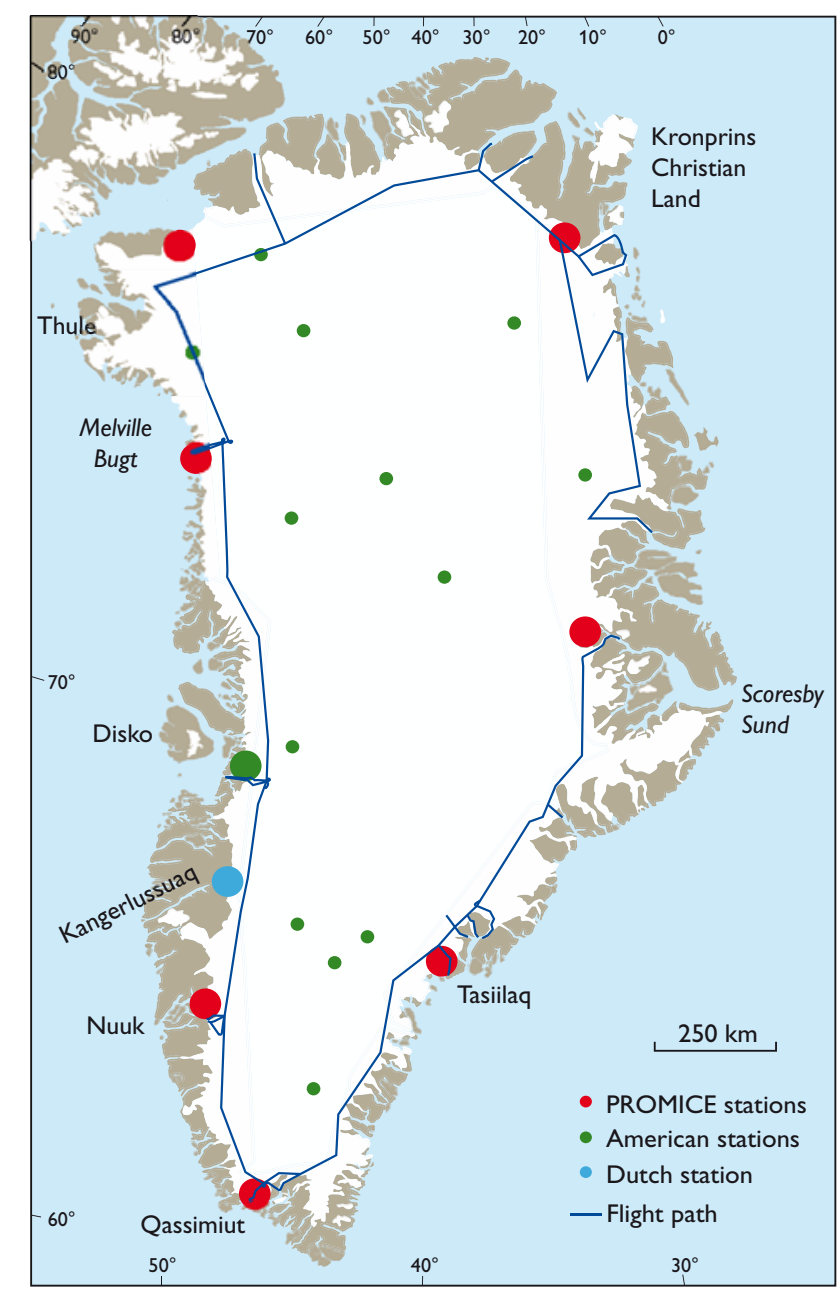

Fig. 1. Overview map showing current and future PROMICE activities. Large dots signify several stations along transects in the ablation zone of the ice sheet, small dots signify individual stations in the accumulation area. By summer 2007, six PROMICE stations were in operation on the ice-sheet margin: two near Tasiilaq, two near Nuuk, one in Melville Bugt and one in South Greenland near Qassimiut. The dots near Thule, Kronprins Christian Land and inner Scoresby Sund signify locations of future station transects to be established over the next three years. The flight lines show the PROMICE flight in August 2007, covering the entire margin apart from a short high elevation segment in East Greenland. Note that the flight paths also pass down 20 of the most significant outlet glaciers from the Greenland ice sheet.

*Peter Gravesen, Signe Bech Andersen, Dirk van As, Michele Citterio, Robert S. Fausto, Søren Nielsen, Hans F. Jepsen, Steen Savstrup Kristensen, Erik Lintz Christensen, Lars Stenseng, Rene Forsberg, Susanne Hanson and Dorthe Petersen 
sheet surface melting and its climatic causes can be effectively monitored in all geographical regions of the Greenland ice sheet. The observations from the station network provide the input to perform the spatially distributed modelling of the surface melting necessary to quantify the total meltwater runoff from the Greenland ice sheet. Such modelling has previously relied on observational data from coastal stations in a maritime climate quite different from stations located at the ice-sheet margin and from stations in the accumulation zone, complemented only by the measurements from the few U.S. and Dutch stations on the ice-sheet margin in West Greenland (Box et al. 2006). The innovative GEUS station setup includes measurement of air temperature, relative humidity, wind speed and direction, atmospheric pressure, incoming and outgoing short- and long-wave radiation, ice temperature, surface velocity, snow depth and ice ablation (Fig. 2). The climate and ice temperature data allow calculation of the complete surface-energy balance. Together with the snow depth measurement, these data make it possible to determine the specific cause of an observed change in surface melt. This implies that we will be able to answer questions such as whether the impact on ice-sheet ablation of rising air temperatures is offset by a corresponding increase in snow precipitation. The data are stored locally in the data logger, but are also transmitted by satellite to GEUS at regular intervals during the melt season, when solar panels deliver the necessary additional power and the data are most crucial. Figure 3 shows some samples of transmitted data. Station power and

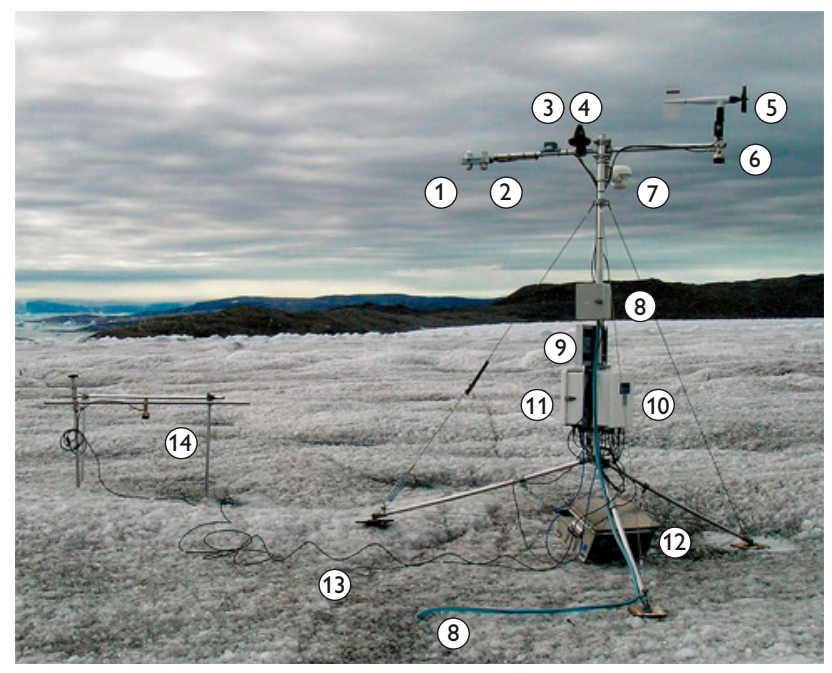

Fig. 2. The new PROMICE automatic mass-balance station, in this case the station with the lowest elevation on the Greenland ice-sheet margin near Tasiilaq, East Greenland. 1, short-wave radiation (in/out); 2, longwave radiation (in/out); $\mathbf{3}$, station tilt; $\mathbf{4}$, satellite transmitter; $\mathbf{5}$, wind speed and direction; 6, snow height (sonar); 7, air temperature and relative humidity; $\mathbf{8}$, ablation (pressure sensor); $\mathbf{9}$, solar panel; 10, dogger logger enclosure; 11, GPS and multiplexer enclosure; 12, battery box; 13, ice temperature 0-10 m (thermistors); 14, ablation (sonar and stakes).
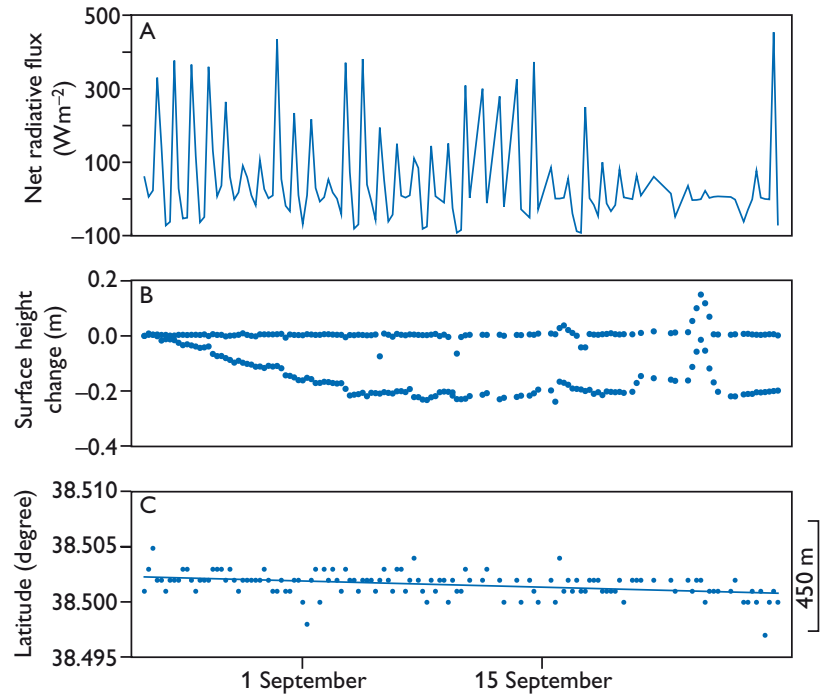

Fig. 3. A: Net radiative flux measured by a CNR-1 instrument, used on the PROMICE stations in 2007. The CNR-1 measures incoming and outgoing short- and long-wave radiation and enables calculation of the surface albedo. B: Snow depth and ablation, measured respectively by a SR-50 sonic ranging device installed on the station tripod and on stakes drilled into the ice. $\mathbf{C}$ : Latitudinal movement of the station recorded by the GPS. All graphs have been produced from satellite-transmitted data received at GEUS.

tilt are also monitored in order to minimise costly maintenance visits.

Generally, station visits by helicopter constitute the main expense in operating the network on the ice-sheet margin. This fact has prompted the development of a new type of ablation sensor at GEUS, based on measuring the pressure of anti-freeze liquid at the end of a flexible, closed hose inserted into the ice to a depth of $30-40 \mathrm{~m}$. As the ice melts, the length of the hose in the ice diminishes, lowering the pressure exerted by the liquid column on the sensor at the bottom of the hose. The top of the hose is connected to a liquid reservoir at a fixed level on the station, making it possible to deduce ice-sheet surface melt from pressure change. An early version of the system has been described by Bøggild $e t$ al. (2005). Once this system is operational, it should in theory be possible to leave the station unattended for as long a time as it takes the hose to melt out of the ice, i.e. more than 5 years, as the remaining part of the station is 'floating' on the ever-changing ice surface. In practice, stations can rarely be left unattended in the harsh environment on the ice-sheet margin for that long, and most instruments would in any case require calibration or maintenance at more regular intervals. However, even a reduction of visits from every year to every second year is substantial. Currently, the pressure-sensor system is supplemented by a more traditional set up with a sonic ranging device mounted on stakes drilled into the ice. The 
sonic-ranger system requires annual visits for re-drilling of stakes, but is necessary as long as the pressure-sensor system is not completely reliable. Both systems record ice melt on an hourly basis, yielding the perfect validation data for determining the individual energy-balance components from the climate data collected.

\section{Quantifying the mass loss caused by iceberg calving}

Iceberg calving from the outlet glaciers of the Greenland ice sheet, often termed the ice-dynamic mass loss, is responsible for most of the acceleration in the mass loss during the last decade (Rignot \& Kanagaratnam 2006). To quantify this part of the mass loss, we combine an airborne survey yielding surface elevation and ice depth across the entire ice-sheet margin, with ice-sheet surface velocity derived from satellite radar. The ice-dynamic mass loss is then derived by calculating the ice flux from the interior of the ice sheet towards the outlet glaciers, while correcting for the surface melt between the flux gate and the calving front of the glacier (Rignot $\&$ Kanagaratnam 2006). The route chosen complements the airborne ice-sheet elevation measurements carried out by U.S. researchers. The route was designed to cover the accumulation zone and the centre line of the main outlet glaciers of the Greenland ice sheet (Krabill et al. 2004). The first airborne survey within PROMICE was carried out in August 2007, measuring ice-sheet elevation with a Riegl scanning laser altimeter (Forsberg et al. 2001) and ice-sheet thickness with a $60 \mathrm{MHz}$ coherent ice-penetrating radar (Christensen et al. 2000). An example of the radar data is shown in Fig. 4. The airborne survey will be repeated every two or three years to monitor temporal changes in the elevation of the Greenland

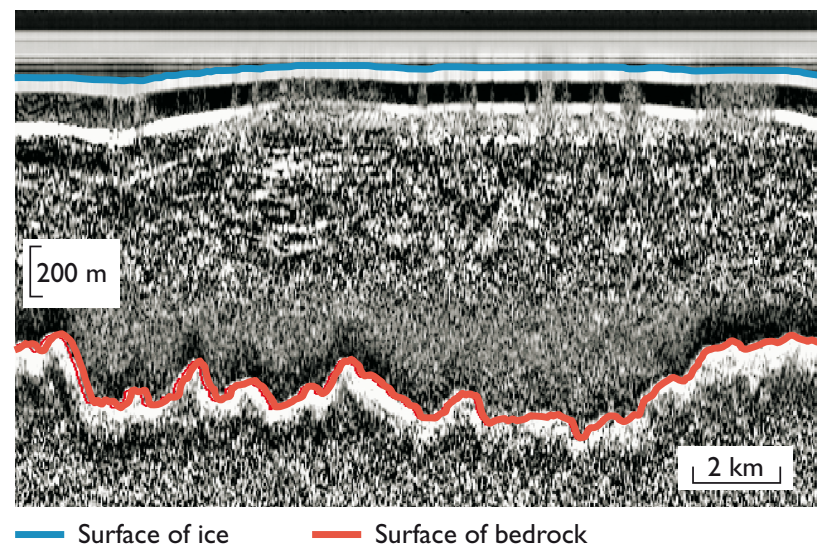

Fig. 4. Data from an ice-penetrating radar. The data have been postprocessed and interpreted to determine the base and surface of the ice sheet at a site in West Greenland. Eventually the ice thickness is determined using the radar reflection from the bedrock in combination with laser altimeter measurements of the ice-sheet surface. ice-sheet margin. The radar had difficulties penetrating the ice sheet in the southernmost part of Greenland, probably due to the extensive surface melting experienced in 2007 and the fact that the survey was carried out in August at the peak of the melt season. The time of year had been selected to minimise the influence of snow depth on the elevation measurements, but may have to be shifted to the spring for future surveys in order to obtain the ice-sheet thickness.

A new P-band radar is currently being developed at the Technical University of Denmark for the European Space Agency. This may replace the older $60 \mathrm{MHz}$ radar on future surveys, if it is more successful in retrieving bedrock returns beneath the ice sheet and is made available for our use.

\section{Monitoring the change of glaciers and ice caps in Greenland}

In addition to the Antarctic and Greenland ice sheets, melting of glaciers and ice caps around the world is contributing significantly to the present-day sea-level rise, and yet almost nothing is known about the current state of the c. 20000 glaciers and ice caps in Greenland. To remedy this lack of knowledge, PROMICE aims at delivering glacier and icesheet outlines to the Global Land Ice Measurements from Space (GLIMS) project, in order to compile a complete inventory of Greenland glaciers and ice caps as well as the icesheet margin. Representative glaciers can be selected from the inventory for detailed volume-change studies of the reaction to climate change and used for up-scaling to larger regions.

The island of Disko in West Greenland was chosen as a test region to develop the methodology for a number of reasons: (a) vectorised maps and elevation contours are available from an airborne survey in 1985; (b) the island is covered by a recent Landsat 7 ETM+ satellite image, facilitating a comparison over a 16-year period; (c) the island is covered by the Glacier Inventory of West Greenland (WGGI) (Weidick et al. 1992); and (d) the island exhibits a wide range of glacier types and problems representative for Greenland as a whole. The WGGI covers more than 5000 glaciers, and is published as a map compilation including a table summarising glacier specific data, such as area, elevation span and orientation. A digital version of the table was checked for errors and included in the Geographic Information System, ArcGIS. Glacier positions needed manual correction due to the limited precision listed in the inventory table. The relevant inventory maps were scanned, geo-referenced and likewise imported into ArcGIS, in order to yield additional information on glacier extent during the Little Ice Age (LIA) as derived from aerial photographs. A Landsat 7 ETM+ image from 2001 available from the Global Land Cover Facility was utilised to obtain a more recent inventory of the glaciers on 
Disko, using the GLIMS algorithm (Paul \& Kääb 2005). A $50 \mathrm{~m}$ resolution digital elevation model was created from the $100 \mathrm{~m}$ elevation contours of the 1985 map, to assist in determining ice-flow divides and orientation controls on glacier sensitivity to climate change.

Preliminary results show that in the period 1985-2001, glaciers on Disko retreated by $8 \%$, whereas no significant areal change could be determined $(<0.5 \%)$. It was also found that the WGGI could not be used for determination of glacier area change since the LIA, but that the glaciers on the island of Disko had retreated 44\% between the LIA and 2001. The initial results thus point to at a more limited reaction to recent warming trends in West Greenland, compared to the strongly responding glaciers and ice caps in Alaska (Arendt et al. 2002).

\section{Outlook}

The data acquired by the monitoring programme will be stored in a database constructed for the purpose at GEUS. So far, the process of defining the database requirements and user needs has been initiated. Once the monitoring programme is operational, data will be made available within a year from acquisition through this database. Already at this early stage, PROMICE has been woven into a number of research activities, national as well as international, utilising the existing field operations as a vehicle for scientific projects. Through the extensive monitoring programme, GEUS has become a natural partner in most international glaciological research activities on the Greenland ice sheet. The effort is also a strong asset for current and future hydropower investigations by the Greenland Home Rule, as well as for prospecting activities near the ice margin.

Over the next three years, the full station network will be established, the ice-sheet surface velocity software will be finalised and the glaciological modelling tools for estimating melting and dynamic mass loss will be developed and applied. With the new monitoring programme of the Greenland ice sheet, we will not only be able to provide an answer to how much the Greenland ice sheet contributes to global sea-level rise, but also make it possible for the global research community to gain access to key data sets to conduct their own investigations.

\section{Acknowledgement}

The Programme for Monitoring of the Greenland ice sheet (PROMICE) is partly funded by DANCEA under the Danish Ministry of Climate and Energy.

\section{References}

ACIA 2005: Arctic climate impact assessment, 1042 pp. Cambridge: Cambridge University Press.

Arendt, A.A., Echelmeyer, K.A., Harrison, W.D., Lingle, C.S. \& Valentine, V.B. 2002: Rapid wastage of Alaska glaciers and their contribution to rising sea level. Science 297, 382-386.

Bøggild, C.E., Olesen, O.B., Ahlstrøm, A.P. \& Jørgensen, P. 2005: Automatic glacier mass balance observations using pressure sensors. Journal of Glaciology 50(169), 303-305.

Box, J.E., Bromwich, D.H., Veenhuis, B.A., Bai, L.-S., Stroeve, J.C., Rogers, J.C., Steffen, K., Haran, T. \& Wang, S.-H. 2006: Greenland ice sheet surface mass balance variability (1988-2004) from calibrated polar MM5 output. Journal of Climate 19, 2783-2800.

Christensen, E.L., Reeh, N., Forsberg, R., Jørgensen, J.H., Skou, N. \& Woelders, K. 2000: A low cost glacier mapping system. Journal of Glaciology 46(154), 531-537.

Forsberg, R., Keller, K. \& Jacobsen, S.M. 2001: Laser monitoring of ice elevations and sea-ice thickness in Greenland. International Archives of Photogrammetry and Remote Sensing 34, 163-169.

IPCC 2007: Climate change 2007: the physical science basis. Contribution of working group I to the fourth assessment report of the Intergovernmental Panel on Climate Change [Solomon, S. et al. (eds)]. Cambridge: Cambridge University Press.

Krabill, W. et al. 2004: Greenland ice sheet: increased coastal thinning Geophysical Research Letters 31, L24402, doi:10.1029/2004GL021533.

Luthcke, S.B., Zwally, H.J., Abdalati, W., Rowlands, D.D., Ray, R.D. Nerem, R.S., Lemoine, F.G., McCarthy, J.J. \& Chinn, D.S. 2006: Recent Greenland ice mass loss by drainage system from satellite gravity observations. Science 314, 1286-1289.

Paul, F. \& Kääb, A. 2005: Perspectives on the production of a glacier inventory from multispectral satellite data in the Canadian Arctic: Cumberland Peninsula, Baffin Island. Annals of Glaciology 42, 59-66.

Rignot, E. \& Kanagaratnam, P. 2006: Changes in the velocity structure of the Greenland ice sheet. Science 311, 986-990.

Shepherd, A. \& Wingham, D. 2007: Recent sea-level contributions of the Antarctic and Greenland ice sheets. Science 315, 1529-1532.

Steffen, K. \& Box, J.E. 2001: Surface climatology of the Greenland ice sheet: Greenland climate network 1995-1999. Journal of Geophysical Research, 106(D24), 33,951-33,964.

van de Wal, R.S.W., Greuell, W., van den Broeke, M.R., Reijmer, C.H. \& Oerlemans, J. 2005: Surface mass-balance observations and automatic weather station data along a transect near Kangerlussuaq, West Greenland. Annals of Glaciology 42, 311-316.

Velicogna, I. \& Wahr, J. 2006: Acceleration of Greenland ice mass loss in spring 2004. Nature 443, 329-331.

Weidick, A., Bøggild, C.E. \& Knudsen, N.T. 1992: Glacier inventory and atlas of West Greenland. Rapport Grønlands Geologiske Undersøgelse 158, $194 \mathrm{pp}$

\footnotetext{
Authors' addresses

A.P.A., P.G., S.B.A., D.v.A., M.C., R.S.F., S.N. \& H.F.J., Geological Survey of Denmark and Greenland, Øster Voldgade 10, DK-1350 Copenhagen K, Denmark. E-mail: apa@geus.dk

S.S.K., E.L.C., L.S., R.F. \& S.H., National Space Institute, Technical University of Denmark, Ørsteds Plads, Bldg. 348 , DK-2800 Kgs. Lyngby, Denmark.

D.P., ASIAQ-Greenland Survey, P.O. Box 1003, Qatserisut 8, DK-3900 Nuuk, Greenland.
} 